\title{
A New Training Workshop for Students' IELTS Exam Mastering
}

\author{
Rimma Ivanova \\ National Research University Higher School of Economics
}

Correspondence concerning this article should be addressed to Rimma Ivanova, National Research University Higher School of Economics, B. Pecherskaya 25/12, Nizhny Novgorod, Russian Federation, 603155. E-mail: rivanova@hse.ru

\author{
Andrey Ivanov \\ Linguistics University Nizhny Novgorod
}

Correspondence concerning this article should be addressed to Andrey Ivanov, Department of foreign languages, Federal State Budgetary Educational Institution of Higher Education "Linguistics University of Nizhny Novgorod”, 31a ul. Minina, Nizhny Novgorod, Russian Federation, 603155.

E-mail: mslyashenko@mail.ru

\section{Mariya Lyashenko \\ Minin University}

Correspondence concerning this article should be addressed to Mariya Lyashenko, Department of foreign languages, Minin’s University, 9 Chelyuskintsev, Nizhny Novgorod, Russian Federation, 603004.

E-mail: mslyashenko@mail.ru

\begin{abstract}
The paper is devoted to the problem of improving written communication skills in the university. It is intended to underline the importance of mastering writing skills when teaching a foreign language. Much attention is paid to teaching experience and approaches for students' mastering of the IELTS (International English Language Testing System) exam. This article is intended to fill the gaps in methodological and pedagogical aspects of teaching description of visual information materials in English. The authors worked out and implemented a new training workshop which is aimed at teaching and practicing graph description of visual information. Based on the curriculum a new syllabus has been drafted that provides further distribution of thematic, lexical and grammatical material given the specific nature of graphical material. The authors propose a two-stage teaching approach and methodological algorithm about how to work out exam strategies and form the required exam competences. The article highlights the outcomes and the challenges that are likely to arise when implementing the approach suggested by the authors. The proposed methodology can be used as a part of general foreign language training.
\end{abstract}

Keywords: IELTS, language writing skills, written communication, exam training, description of visual materials

Foreign language teaching methods in post-Soviet times have invariably neglected intensive techniques that could help to develop foreign language writing skills, although any school or university textbook generally contains a large number of written assignments for in-class and out-of-class training.

The USSR of the mid twentieth century had a focus on foreign language education based on the principles of grammar-translation method involving a detailed study of grammar rules and their subsequent practice 
through drilling exercises. Writing was used solely as a means of teaching a foreign language. In the late 1980s-90s foreign language teaching methods evolved qualitatively: Basic skills essential for oral communication were given top priority. Thus, special emphasis was placed on generating and developing verbal skills. It is widely accepted that modern foreign language education stresses the importance of teaching both oral and written communication, so currently all types of speech activities are addressed equally. Writing is no longer isolated from other speech activities, but it is rather an integral part of a comprehensive teaching method since written communication offers multifold opportunities to form the mechanism of foreign speech production.

Following the requirements of the Bologna Convention, general principles of teaching the English Language as an academic discipline to undergraduate students at higher educational institutions are unified both across Europe and Russia. That is why the role of writing as a communication activity in the academic process is growing.

This academic activity involves several types of written communication:

- filling in questionnaires;

- writing personal / formal letters;

- making a CV;

- writing applications;

- describing graphs;

- writing reviews;

- writing annotations;

- writing reports;

- writing compositions / essays;

- writing research papers;

- writing course works;

- writing graduation theses.

In written communication, students are expected to describe events, facts or phenomena; report and request detailed information; express personal standpoint or stance; write reviews on books or movies; comment on events or facts with substantiated reasoning using emotional, expressive or evaluation means; compare personal experience with that of the native speaker of the target language; use synonymous means of expression. When creating such written texts, it is crucial to bear in mind their structural logic and composition. Many of those competences are mastered by students when learning a foreign language at school.

In the course of university studies, students improve their written communication skills by preparing course works or graduation theses. But only during English language tutorials, undergraduate students working towards a Bachelor's Degree get acquainted with a new type of written communication - description of visual information materials, including line, surface, pie charts, amplitude graphs, maps, schematic pictures, and tables.

Practice shows that written tasks of that kind are rather complicated but highly essential types of written communication, as they involve description of various visual graphical images using at least 150 words within a set period of time (20 minutes).

Due to their considerable complexity and specificity, written tasks related to describing graphical information are taught at an advanced level only. Such training would be unreasonable unless students have sufficient vocabulary and the linguistic component of their communicative competence is largely formed. With this in mind, the tutor can primarily focus on forming and developing pragmatic and sociolinguistic components of the communicative competence.

\section{Materials and Methods}

\section{Methodology of Writing Skills Development}

Numerous studies into teaching methods of writing in a foreign language prove a growing interest in written communication. That is why current methods of foreign language education place special emphasis on strategies of preparing for international exams, including IELTS (Sahanaya, Lindeck, \& Stewart, 2006). However, the scope of surveys into the experience gained while preparing students for written tasks and related in particular to describing graphical visual materials is rather scarce (Chaudron, 1995; Hyland, 2009). Precisely speaking, most achievements of this kind relate mainly to general methodological guidelines required to prepare students for academic writing, but only partly address such issues as describing charts, maps and schemes (Sommer, 1989; Bachman, 1990; Farhady, Jafarpoor, \& Birjandi, 1994; Wray \& Lewis, 1997; Bondareva, 1999; Tatarinova, 2005; Zhurbenko, 2008).

An analysis of contemporary scientific sources undertaken by the authors in the given field showed no determined efforts or methodologically sound works that would seriously focus on ways and means of tackling challenges that arise while preparing students for describing visual graphical materials with regard to the requirements of international English language exams. This article is intended to fill the gaps in methodological and pedagogical aspects of teaching this type of written communication.

Writing skills have rarely been given due attention by Russian tutors - in methodological respect writing has been considered a specific type of speech activity that requires focused instruction. Foreign language teaching methods applied to develop writing skills were actually based on the existing practice of mastering 
writing skills in the native language; however, they are far from being equal. When analysing speech activities, the primary focus was and still is on speaking as a priority and writing as an auxiliary skill.

Researchers that recognise a critical role of writing as an efficient activity relevant to mastering the language note that writing indeed promotes linguistic competences and along with reading makes up a linguistic analytical activity (Bramki \& Williams, 1984). Within the modern methodological concept, this fact helps to define writing not only as a means but also as a goal of teaching a foreign language since writing creates favourable conditions for forming and consolidating oral and written communication skills.

Irrespective of the type of written tasks a student performs, writing gives them ample opportunities for independent and arbitrary making up of a statement with due respect for the rules and norms of the target language because indeed a written text helps to assimilate the rules of a different language and accelerates internalisation of foreign language speech patterns, which in turn contributes to the formation and the consolidation of mechanisms of foreign language acquisition (Danilina, 1981, p. 42).

More importantly, writing helps to seize a special algorithm focused on curtailing or folding an enlarged statement in line with the generalised semantic scheme, which in essence is the process of transforming external speech into an internal one.

The highest level of foreign language command implies perception of the information in a way that the recipient dismisses the linguistic context of speech but keeps its semantic content expressed in a free form different from the original. Ellis and Beaton (1993) as well as Widdowson (2003) point out that writing promotes linguistic thinking that is understood as a means of navigation in the language material based on linguistic conceptual images. Linguistic thinking is implemented through solving linguistic problems. An operational feature of this type of thinking involves updating linguistic benchmarks in the subject's conscience to extract semantic information from the text during speech perception and to build a message based thereon at the moment of speech. According to the above authors, writing-based work on the text promotes faster formation of untranslatable understanding of foreign speech.

Further speaking about the importance of mastering writing skills, it is crucial to highlight that written communication forms an integral part of a cognitive process of students' critical thinking: any mistakes in the target language are promptly and clearly identified in written speech, thus making it an optimal means of control in learning a foreign language.

Automation of written text manipulation skills and formation of similar abilities with students occur amid constant vocabulary expansion, greater scope and complexity of written tasks: at an early training stage, most training time is devoted to pattern texts, whereas towards graduation the focus shifts to higher complexity tasks associated with a course work or a graduation thesis, both implying much better formed skills of working with written texts.

In the authors' opinion, it is undoubtedly essential to teach students to describe charts, drawings, schemes or diagrams of various thematic scope and complexity in view of the growing society informatisation, and ever-increasing amount of information. That is why preparing students for international language exams such as IELTS currently involves planning and achieving a series of training outcomes, including the following:

- ability to read information from the graphical medium and transmit it in writing using the target language thus providing an objective and reliable description of the graph (chart, diagram, drawing, map, etc.);

- ability to make a written report on the subject passing no judgment of one's own;

- ability to use appropriate lexical and grammatical stock to describe graphical materials;

- ability to choose the most accurate and comprehensive strategy to quickly and adequately describe graphical materials within a certain period of time;

- ability to use special patterns when creating written texts;

- $\quad$ strong orthographic skills;

- basic knowledge of business writing;

- sustainable skills of independent work.

Speaking and writing constitute a multidirectional actualisation of a single verbal-communicative human function (Zimnyaya, 2000, p. 183); that is why when teaching writing as one of the key types of learning speech activity due account needs to be taken of the following challenges that are faced if working with written texts:

- perception and processing of the information are largely mediated by its presentation form;

- productivity of the recipient's speech activity is determined by the quality and depth of understanding of the information received;

- quality of the final product is directly dependent on the extent to which writing and verbal skills are developed with a student, on his ability to choose and correctly apply speech material required to create a text-description.

All types of speech activity are united by a single means of thought formation with apparent differences in the use of means and methods of speech transfer. In teaching writing, it is crucial to send materials that are 
to be adopted through an audiovisual channel because when making up a written statement, students mainly rely on well-developed verbal and writing skills. The statement has not only length but depth which is meaningful for the speaker or the writer (Milrud, 2005 , p. 95); the latter should create lexically and grammatically correct texts in a foreign language.

Bearing in mind methodological aspects, it is worth noting that the task to describe various visual materials implies a certain level of written and verbal skill formation. Creating a text-description in a written form is viewed as one of the most valuable scholastic and professional abilities and forms an integral part of a student's both academic and practical activity. Thus, in the context of cross-cultural communication and the development of sociolinguistic competence, training to write secondary texts continues to be highly relevant.

When teaching to perform any tasks related to such an academic activity as description of visual information materials, a number of teaching methods including conscious-practical, communicative, audiovisual and integral methods are commonly used.

These methods are to some extent applied to teach students all types of speech activity, but only when teaching to describe charts, diagrams, drawing and schemes of various sorts such methods collectively demonstrate their efficiency.

\section{Results}

\section{Description of Graphical Information in English: A New Training Workshop}

With due regard to the requirements imposed by the Federal State Educational Standards adopted by the Ministry of Education and Science of the Russian Federation, preparation for writing tests is arranged for students with different levels of language training:

- high school students planning to enter foreign universities;

- undergraduates studying for a Bachelor's Degree;

- students planning to study either for a Master's Degree or PhD;

- graduates intending to improve qualifications in English or undergo training abroad.

Written communication skills are formed with junior students when making IELTS Writing Task I at the stage of profile-based training in the context of a future professional activity, thus contributing to the development of a professionally-oriented foreign language communicative competence. When training students for an international exam, graph descriptions prove to be the most complicated written task although the skills of drawing up letters and writing essays are assumed to have been generally formed at school.

Since a certain type of visual information materials promotes a qualitatively different writing skills focus, the authors have developed Graph Description Activator, a workshop meant to train students for the IELTS test. Workshops are generally looked at as an innovative form of development of communicative skills at the Higher School of Economics (Velikaya, 2015, p. 61).

The training session consists of 10 topics each corresponding to exam topics and has a well-defined structure.

The topics have been identified with due regard to the following aspects:

- type of graph;

- vocabulary focus;

- grammar focus.

Based on the curriculum, a new syllabus has been drafted that provides the following distribution of thematic, lexical and grammatical material given the specific nature of the graphical description required.

Table 1

Training stages and skills being received

\begin{tabular}{|c|c|c|c|}
\hline $\begin{array}{c}\text { Type } \\
\text { of Graph }\end{array}$ & $\begin{array}{l}\text { Grammar } \\
\text { Focus }\end{array}$ & $\begin{array}{l}\text { Vocabulary } \\
\text { Focus }\end{array}$ & $\begin{array}{l}\text { Skills } \\
\text { Focus }\end{array}$ \\
\hline $\begin{array}{l}\text { 1. Types of } \\
\text { graphs } \\
\text { 2. Main } \\
\text { principles } \\
\text { of writing }\end{array}$ & $\begin{array}{l}\text { Punctuation } \\
\text { Sentence } \\
\text { structure } \\
\text { Active } \\
\text { grammar: } \\
\text { construc- } \\
\text { tions for the } \\
\text { formal style }\end{array}$ & $\begin{array}{l}\text { Formal / in- } \\
\text { formal range } \\
\text { of vocabulary }\end{array}$ & $\begin{array}{l}\text { Creating a } \\
\text { structure (sen- } \\
\text { tence, para- } \\
\text { graph, text) } \\
\text { Style } \\
\text { Analysing the } \\
\text { question }\end{array}$ \\
\hline $\begin{array}{l}\text { A line } \\
\text { graph }\end{array}$ & $\begin{array}{l}\text { Present } \\
\text { Tense forms }\end{array}$ & $\begin{array}{l}\text { Collocation } \\
\text { related to } \\
\text { health }\end{array}$ & $\begin{array}{l}\text { Making a point } \\
\text { Writing an } \\
\text { introduction } \\
\text { Organising } \\
\text { ideas }\end{array}$ \\
\hline A pie chart & $\begin{array}{l}\text { Past Tense } \\
\text { forms }\end{array}$ & $\begin{array}{l}\text { Collocation } \\
\text { related to } \\
\text { health } \\
\text { Collocations } \\
\text { with nouns }\end{array}$ & $\begin{array}{l}\text { Writing the } \\
\text { main body } \\
\text { Developing the } \\
\text { theme } \\
\text { Describing the } \\
\text { trends }\end{array}$ \\
\hline A pie chart & $\begin{array}{l}\text { Future Tense } \\
\text { forms }\end{array}$ & $\begin{array}{l}\text { Collocation } \\
\text { related to } \\
\text { nature } \\
\text { Collocation } \\
\text { with verbs } \\
\text { Prepositions }\end{array}$ & $\begin{array}{l}\text { Emphasising } \\
\text { the point } \\
\text { Supporting } \\
\text { details }\end{array}$ \\
\hline A process & Passive voice & $\begin{array}{l}\text { Collocation } \\
\text { related to } \\
\text { language } \\
\text { Cause and } \\
\text { effect verbs } \\
\text { and nouns }\end{array}$ & $\begin{array}{l}\text { Describing } \\
\text { stages of devel- } \\
\text { opment }\end{array}$ \\
\hline
\end{tabular}




\begin{tabular}{|c|c|c|c|}
\hline A process & $\begin{array}{l}\text { Degrees of } \\
\text { comparison } \\
\text { Articles }\end{array}$ & $\begin{array}{l}\text { Collocation } \\
\text { related to } \\
\text { technology } \\
\text { and science } \\
\text { Adjectives } \\
\text { and adverbs }\end{array}$ & $\begin{array}{l}\text { Comparing and } \\
\text { contrasting }\end{array}$ \\
\hline A bar chart & $\begin{array}{l}\text { Countable / } \\
\text { uncountable } \\
\text { nouns } \\
\text { Articles } \\
\text { Numbers }\end{array}$ & $\begin{array}{l}\text { Collocation } \\
\text { related to } \\
\text { culture } \\
\text { Words and } \\
\text { phrases } \\
\text { expressing } \\
\text { quantity }\end{array}$ & $\begin{array}{l}\text { Working with } \\
\text { numbers and } \\
\text { quantities } \\
\text { Explaining the } \\
\text { trend }\end{array}$ \\
\hline A bar chart & $\begin{array}{l}\text { Infinitival } \\
\text { and gerundi- } \\
\text { al construc- } \\
\text { tions }\end{array}$ & $\begin{array}{l}\text { Collocation } \\
\text { related to } \\
\text { travel } \\
\text { The usage } \\
\text { of synonyms } \\
\text { and antonyms }\end{array}$ & $\begin{array}{l}\text { Paraphrasing } \\
\text { Avoiding word- } \\
\text { iness }\end{array}$ \\
\hline A table & $\begin{array}{l}\text { Defining and } \\
\text { non-defining } \\
\text { clauses }\end{array}$ & $\begin{array}{l}\text { Collocation } \\
\text { related to } \\
\text { business } \\
\text { Derivatives }\end{array}$ & $\begin{array}{l}\text { Writing the } \\
\text { conclusion } \\
\text { Summarising } \\
\text { the ideas }\end{array}$ \\
\hline Review & $\begin{array}{l}\text { Finding } \\
\text { mistakes }\end{array}$ & & Proof reading \\
\hline
\end{tabular}

In the course of studies students are offered various thematic tasks that facilitate their prompt and efficient involvement into the work related to describing various charts, diagrams and schematic drawings. The authors find it reasonable to familiarise students concerned with a variety of typical assignments that are successfully used by the authors in the teaching process.

Types of possible tasks

1. Understanding a task/question. Analysing the graph:

- true/false questions;

- matching;

- completing a gapped text;

- analysing the graph structure;

- analysing the paragraph structure.

2. Grammar focus:

- completing the sentences using different tense forms / ing-forms / articles etc.;

- rewriting the sentences using passive forms;

- matching the grammar pattern with the example;

- underlining and correcting the mistakes.

3. Vocabulary focus:

- studying the collocations and complete the sentences;

- transforming the sentences using derivatives / synonyms / antonyms;

- finding the correct/incorrect words in the sentences;

- deciding where you can use the phrases in the paragraph;

- completing the sentences with the expressions of quantity / preposition / relative pronoun / collocations etc.;

- matching the expression with the definition.

4. Writing skills:

- rewriting the sentences using the words given;

- finding the examples of linking devices;

- finding the examples of formal/informal style;

- sketching the diagram according to the description;

- completing the introductory/concluding phrases;

- matching the paragraph with the graph.

The proposed tasks are formed in view of the methodological principles described above and finally help to obtain the desired end product - a written text with a consistent description of a chart, diagram or map image. Such a text meets the requirements imposed by examiners authorised to check final written papers of the IELTS test.

Tasks based on visual information materials are performed in line with a carefully designed plan and subject to an extensive use of interactive technologies: video materials, podcasts, educational web-sites, and interactive flash cards. Such information support contributes to students' growing interest in the discipline in general and in this type of activity in particular.

One of the key elements of the workshop task flow is the choice of strategy to describe a particular type of chart. Essential strategies are taught in two stages.

1 . The first stage requires the processing of the visual information materials. The main goal there is to ensure careful graph (chart, diagram, drawing, scheme, etc.) reading, and graph data analysis.

This stage involves presentations, video materials, and Internet resources. The tutor demonstrates strategies of dealing with visual information materials that suggest the following activities:

- note maximum and minimum peaks marked on the graph;

- indicate significant trends in each segment (sector);

- define key parameters that would later serve the basis for a text-description;

- avoid irrelevant details and explanations.

Demonstration of the essential vocabulary, its drilling and activation make up another substantial part of training. Basic vocabulary helps to describe the elements of visual information materials and the socalled linking units that serve to unite separate parts of the text. Lexical material is mastered using specially designed flash cards posted on the Internet web page or any information-educational platform.

No less attention at this stage is given to basic grammar. The goal is to improve grammar skills, i.e., to activate grammar patterns obligatory for written text-descriptions. 
After such preparation, a student gets down to writing his own text. First of all, he needs to identify the type of graphical information (chart, diagram, scheme, drawing, map, etc.), give its brief formal description with due regard to most essential, inherent characteristics of this type, and then interpret the information contained in the graph.

2 . The second stage requires laying out and editing a written text.

Students are advised to critically reflect on and review the text they have written in order to avoid such mistakes as personal opinion or comments, and to paraphrase sentences that fail to fully perform the informative function. Students need to make sure that their text is consistent, coherent, and reliable, fully conveys graphical information, and contains the required relevant connectors between the parts. Besides, before making a test the students are offered to get acquainted with graph descriptions patterns given in the pool of ready-made description essays.

The authors of the course place particular emphasis on group and pair work as a means to arrange collective thinking activity aimed to improve motivation based on the collaborative (joint) education principle.

Students at the final stage are required to check and assess groupmates' test papers.

Examples of students' graph description are given below.

The writing task for student $X$.

The diagram below shows the process for manufacturing juice of a direct extraction. Summarise the information by selecting and reporting the main features, and make comparisons where relevant. You should spend about 20 minutes on this task. Write at least 150 words.

The graph description made by student $X$.

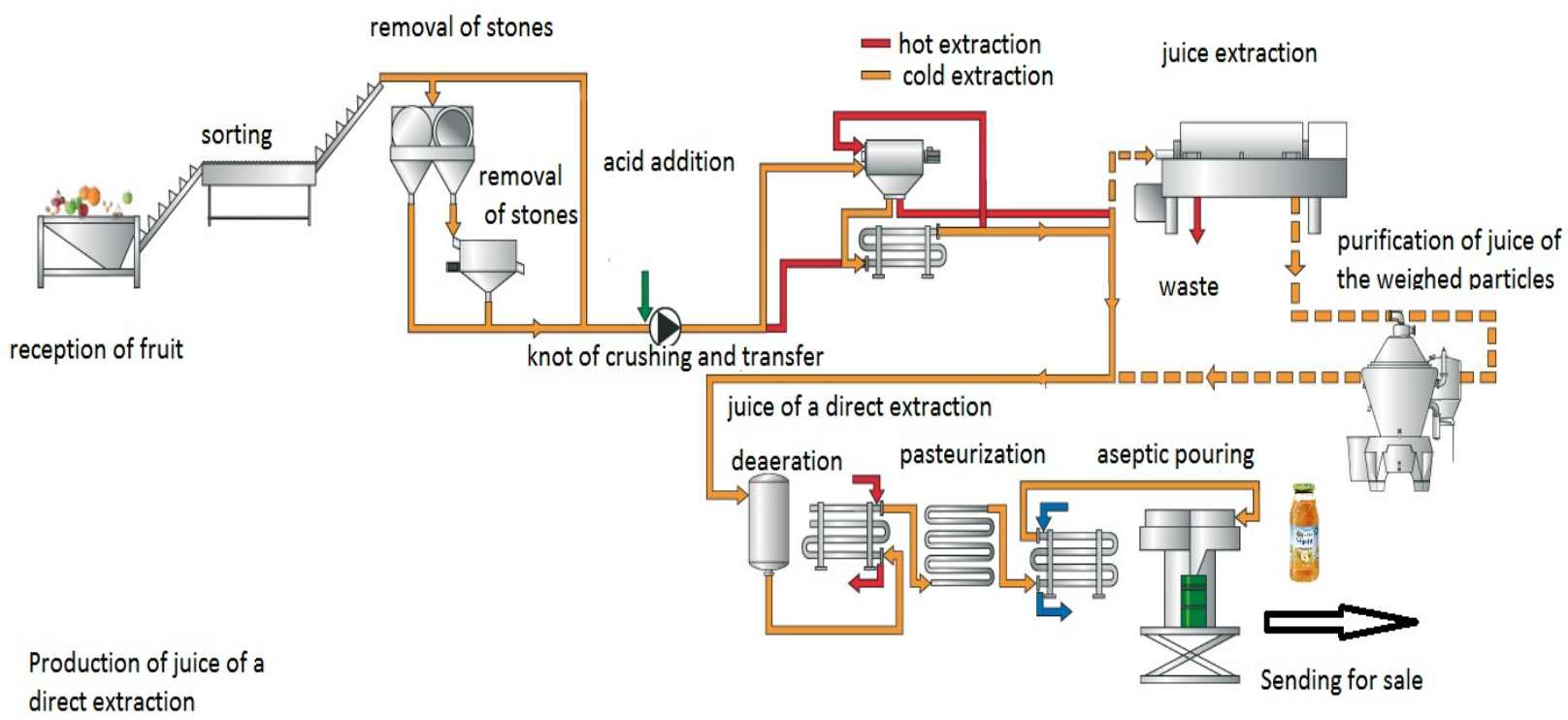

Figure 1. Production of juice of a direct extraction.

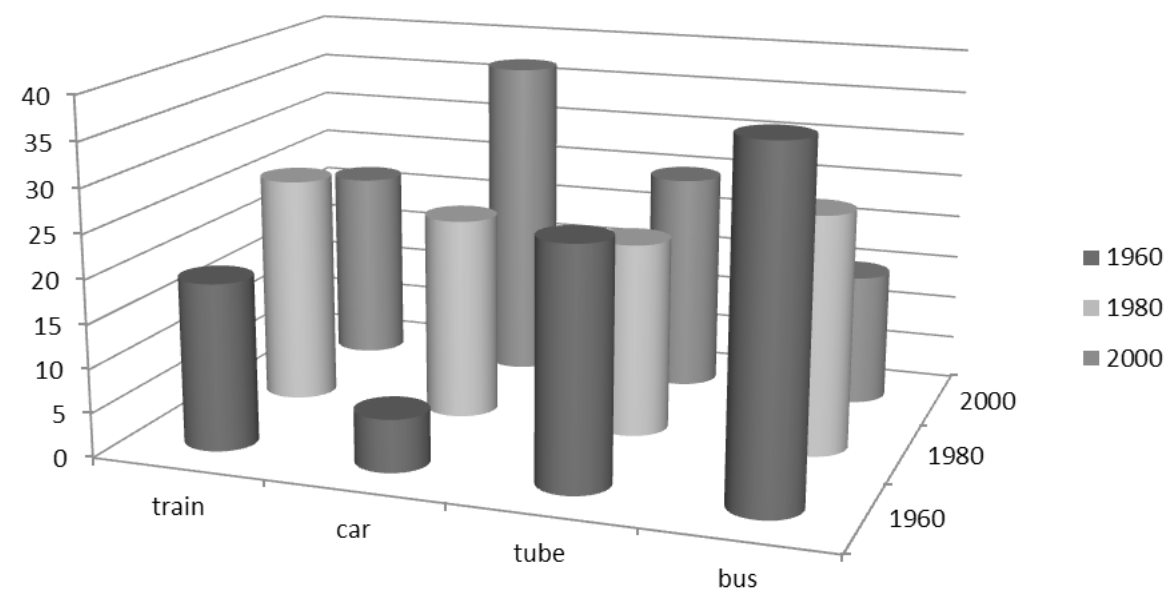

Figure 2. Mode of transport and years. 


\section{The Apple Juice Manufacturing Process}

This scheme illustrates the most widespread method of producing the apple juice.

To begin with, the process consists of approximately nine stages. First of all, it is impossible to prepare juice without ripe fruits grown on a farm. Once, when ripening is done, it is supposed to collect received harvest and transport it to one of the factories. Then, having delivered apples, workers must clean them from dirt and put into fresh water. Following this, pure fruits are likely to be sliced up by means of huge cutting machines. Next, they can be squeezed using extractors, and apples finally turned into the liquid. After this stage, resulting juice is usually packed into boxes and delivered to a local store.

To conclude, it is necessarily to note the process of making juice not to be a bed of roses because of its difficulty. Nevertheless, it has always been one of the most popular beverages, which is drunk all over the world.

The writing task for student $Y$.

The graph shows the different modes of transport used to travel to and from work in one European city in 1960, 1980 and 2000. Summarise the information by selecting and reporting the main features, and make comparisons where relevant. You should spend about 20 minutes on this task. Write at least 150 words.

The graph description made by student $Y$.

\section{Over Time: Modes of Transport}

The chart illustrates changes in the transports used to and from work in a particular European city for 3 years.

Regarding 1960, the greatest number of commuters used buses, about $40 \%$. The figures for other types of transport - tube, car and train - were at approximately $27 \%, 22 \%$ and $19 \%$ respectively.

The bus popularity decreased to about $26 \%$ in 1980 and this fell even further to $15 \%$ in 2000 . In contrast, the use of cars increased significantly to about 23\% in 1980 , before rising steeply to $38 \%$ towards the end of the period. Moving on to the train, the figures increased to about $26 \%$, but this dropped to just over $20 \%$ by 2000 . The use of the tube declined from 1960 to 1980 before rising $25 \%$ in the final year.

In conclusion, the chart indicates that car use increased over the period shown, whereas the use of the bus declined. The figures for tubes and trains both fluctuated over the same period of time.

Many years of preparing students for IELTS international exam have prompted a unique teaching algorithm for Writing Task 1 to be presented as follows:

Methodological Guidelines for Describing Visual

\section{Information Materials}

1. Peruse the information provided

2. Define the type of visual information materials

3. Assess the graphical image

4. Draft a description plan

5. Highlight main trends

6. Examine the details to identify relevant and/ or irrelevant information

7. Make up a written text following a proven structure that includes introductory part, main body, final part

8. Highlight key points using equivalent numerical information available on the graph (chart, diagram, scheme, drawing, map, etc.) as a line of reasoning

9. Use a proper stock of lexical and grammatical tools to make up a text-description

10. Check the text for spelling mistakes

11. Avoid personal opinions or critical remarks towards the matter in question using clichéd structures and opinion words such as 'I think', 'I believe'

12. Avoid describing every fact presented in this or that section of the chart or diagram, or explaining the reasons for arising trends or phenomena

13. Be precise in conveying numerical information available on the graph (chart, diagram, scheme, drawing, map, etc.)

14. Simplify the text-description where necessary to make it comprehensible and understandable to a reader

15. Count the number of words used when making the said assignment

16. Meet the given time of 20 minutes.

Upon completion of the task the student shall pass his written text either to a tutor or to his peer in a pair or group work for further review and analysis.

During the workshops the tutor shall provide students with clear instructions and clarifications the goal of which is to train students for a particular written assignment.

Another crucial aspect of the given algorithm to be followed when writing up a text-description is to build a description of graphical information on active vocabulary and grammar patterns required by the IELTS test format and mastered through various forms of interactive learning. A series of PowerPoint presentations as well as auxiliary online resources have been developed and integrated into the educational process to present graphs and description structure prepared by tutors and/or students.

A written text-description is focused on developing and improving the following competences presented in Table 2. 
Table 2

Competences to be developed (improved), and core results of mastering the discipline

\begin{tabular}{|c|c|c|}
\hline $\begin{array}{l}\text { Type } \\
\text { of Competence }\end{array}$ & $\begin{array}{l}\text { Content } \\
\text { of Competence }\end{array}$ & $\begin{array}{l}\text { Core Results } \\
\text { of Mastering the Discipline }\end{array}$ \\
\hline \multicolumn{3}{|c|}{ Universal Competences } \\
\hline $\begin{array}{l}\text { Native } \\
\text { language } \\
\text { competence }\end{array}$ & $\begin{array}{l}\text { Comprehensive command of the native language and } \\
\text { proficient level of oral and written communication in } \\
\text { the native language }\end{array}$ & $\begin{array}{l}\text { Knows how to use words, their forms, syntactic structures in } \\
\text { accordance with the norms of the literary language, use all } \\
\text { lexical means in accordance with the stylistic differences }\end{array}$ \\
\hline $\begin{array}{l}\text { Foreign } \\
\text { language } \\
\text { competence }\end{array}$ & $\begin{array}{l}\text { Formal language skills, acquisition of lexical, gram- } \\
\text { matical, and phonetic foreign language skills and } \\
\text { ability to apply the acquired skills to achieve commu- } \\
\text { nication goals }\end{array}$ & $\begin{array}{l}\text { Knows how to describe various graphical images thus reach- } \\
\text { ing the goals set in written communication. } \\
\text { Knows how to make clear statements on various topics, ex- } \\
\text { press his/her views on the issue by giving pros and cons }\end{array}$ \\
\hline $\begin{array}{l}\text { Training } \\
\text { competence }\end{array}$ & $\begin{array}{l}\text { Tendency to continuous learning, activity profile re- } \\
\text { arrangement, satisfaction of ever-changing life and } \\
\text { professional ambitions to successfully adapt on the } \\
\text { labor market }\end{array}$ & $\begin{array}{l}\text { Knows how to use knowledge of various branches of science } \\
\text { and apply it in practice }\end{array}$ \\
\hline $\begin{array}{l}\text { Sociolinguistic } \\
\text { competence }\end{array}$ & $\begin{array}{l}\text { Ability to apply the acquired language skills to recog- } \\
\text { nise spelling, lexical, grammar, and other features of } \\
\text { the visual information materials }\end{array}$ & $\begin{array}{l}\text { Knows how to choose and use appropriate language forms } \\
\text { and means depending on the goal of the message. } \\
\text { Knows about stylistic differences }\end{array}$ \\
\hline $\begin{array}{l}\text { Sociocultural } \\
\text { competence }\end{array}$ & $\begin{array}{l}\text { Willingness and ability to hold a dialogue of cultures } \\
\text { that involves knowledge of cultural realities, native } \\
\text { and foreign language realities. } \\
\text { Ability to apply this knowledge in oral and written } \\
\text { communication }\end{array}$ & $\begin{array}{l}\text { Knows about cultural characteristics of other countries, } \\
\text { standards of conduct in a foreign language society. } \\
\text { Knows how to adequately present his/her culture using the } \\
\text { means of the English language }\end{array}$ \\
\hline $\begin{array}{l}\text { Pragmatic } \\
\text { competence }\end{array}$ & $\begin{array}{l}\text { Proficiency in a cluster of communicative behaviour } \\
\text { patterns as a set of communicative norms and tradi- } \\
\text { tions typical of the English-speaking linguocultural } \\
\text { society }\end{array}$ & $\begin{array}{l}\text { Knows how to make clear, logical statements using a re- } \\
\text { quired pool of language tools }\end{array}$ \\
\hline
\end{tabular}

Special Competences

\begin{tabular}{lll}
\hline $\begin{array}{l}\text { Discourse } \\
\text { competence }\end{array}$ & $\begin{array}{l}\text { Ability to generate coherent foreign language state- } \\
\text { ments, arrange logical, consistent, and convincing } \\
\text { speech, use a proper stock of lexical, grammatical and } \\
\text { spelling tools }\end{array}$ & $\begin{array}{l}\text { Knows how to arrange logical, consistent, and convincing } \\
\text { speech }\end{array}$ \\
\hline $\begin{array}{l}\text { Strategic } \\
\text { competence }\end{array}$ & $\begin{array}{l}\text { Ability to use both verbal and nonverbal strategies to } \\
\text { compensate for the gaps in the knowledge of the Eng- } \\
\text { lish language code }\end{array}$ & $\begin{array}{l}\text { Knows how to use both verbal and nonverbal language tools } \\
\text { to achieve communicative goals }\end{array}$ \\
\hline & $\begin{array}{l}\text { Ability to understand, synthesise and analyse infor- } \\
\text { mation }\end{array}$ & $\begin{array}{l}\text { Knows how to express his/her thought in oral or written form } \\
\text { using an appropriate language stock: Commands a large vo- } \\
\text { cabulary in academic and professional spheres and uses it } \\
\text { abpropriately in speech } \\
\text { Linguistic } \\
\text { mampetence }\end{array}$ \\
& $\begin{array}{l}\text { mallerial to create an information message or a review } \\
\text { following the given graphical written structure. }\end{array}$ & \\
& $\begin{array}{l}\text { Ability to understand and generate foreign language } \\
\text { statements in oral and written speech }\end{array}$ &
\end{tabular}

Compared with other activities arranged during the English Language Course, Graph Description Activator is focused on a set of teaching techniques specifically developed to master a particular test exercise, i.e., to train students to make a text-description based on visual information materials for the IELTS exam. This activity is for the first time arranged at the university and as the authors continue to reiterate, requires a painstaking and careful preparation of both the tutors and students.

Being devoted to graph description English classes shows further students' skills improvement. The tutors' experience and the results achieved by students witness versatile chances of the workshop in acquiring both basic and additional competences, because writing, speaking, listening, and reading skills are mastered simultaneously.

Writing skills are subject to current, formative, and summative assessment.

Current assessment involves the following activities performed by students:

1) individual work during practicals in all types of foreign language activities (listening, speaking, reading and writing);

2) separate writing activity based on the communicative task set.

Formative (intermediate) assessment takes place in the middle of the term and is aimed at: 
1) checking skills to describe any types of graphs (charts, tables, diagrams, maps, etc.);

2) identifying the development and automation skills level after finishing the topic.

Summative (final) assessment aims to check students' ability to describe graphical materials of any complexity in line with the scheme proposed and apply description skills in further professional activities.

\section{Discussion and Conclusions}

All the four aspects of speech activity are known to be split in actual communication as follows: listening $-42 \%$, speaking $-32 \%$, reading $-15 \%$, writing $-11 \%$. Although, in the course of studies, writing in terms of percentage is the leastaddressed type of communicative activity, it is a complex psycholinguistic process of perception, recognition and understanding foreign speech associated with processing and transmission of the information received.

The authors' experience proves that using the proposed teaching approach in the academic process when training junior students for one of the IELTS-based tasks is very efficient. The proposed methodology is used in class as part of general foreign language training and may serve for designing and implementing other academic projects and training methods. The crucial feature of the concept underlying a set of methods used to work with graphical materials is that a written text is made up with the help of lexical and grammatical patterns serving as auxiliary means to achieve communicative goals.

Describing charts is a means of creating a text that emerges as a result of performing a series of mental and logical operations, including analysis, synthesis and interpretation of graphical materials, description of its informative elements in students' own words.

The educational value of the methods used to describe graphical information involves improving students' intellectual abilities, developing attention, learning to read various diagrams, creating a written text based on the obtained information, improving competences typically required for a researcher, including responsible attitude to the results of one's work.

When training students it is important to arrange their self-guided work with written texts, because this type of activity can be seen as one of the ways to achieve a major communication-oriented goal, i.e., to teach speaking.

Working with a text-description helps to tackle a number of extra challenges, including:

- intensifying students' speech activity;

- presentation and consolidation of new academic materials;

- developing skills and abilities required for successful implementation of other types of speech activity;

- increased feedback and self-control efficiency.

The proposed workshop offers an interdisciplinary and vocational guidance, since the ability to describe graphical information is universal in nature and highly required in various disciplines such as Mathematical Analysis, Macroeconomics, Microeconomics, Accounting, Time Management, etc. Methods of working with graphical materials can generally find efficient application in English language classes because they aim at forming communication skills both in oral and written forms.

The ability to make an adequate and professional description of graphical information is equally important for upperclassmen, especially while preparing and defending a graduation thesis: Requirements introduced to defend a graduation project include graduate's mandatory skills of analysing and interpreting the results of research work during defence which are usually presented in graphical form.

\section{References}

Bachman, L. F. (1990). Fundamental considerations in language testing. Oxford, UK: OUP.

Bondareva, V. V. (1999). Obucheniye pis'mu na inostrannom yazyke: Nazrevshaya neobkhodimost' [Teaching writing in a foreign language: The urgent need]. ELT News \& Views, 9, 5-7.

Bramki, D., \& Williams, R. (1984). Lexical familiarization in economics text and its pedagogic implications in reading comprehension. Reading in a Foreign Language, 2(1), 169-181.

Chaudron, C. (1995). Second language classrooms: Research on teaching and learning. Cambridge, UK: CUP.

Danilina, K. V. (1981). Vzaimodeystviye vidov rechevoy deyatel'nosti pri obuchenii inostrannym yazykam [Interaction of verbal skills when teaching foreign languages]. In A. I. Mirlis, V. I. Mitrokhina \& E. P. Chaplygina (Eds.), Prepodavaniye Russkogo Yazyka Aspirantam-Inostrantsam (pp. 41-48). Moscow, USSR: Nauka.

Ellis, N. C., \& Beaton, A. (1993). Psycholinguistic determinants of foreign language vocabulary learning. Language Learning, 43(4), 559-617.

Farhady, H., Jafarpoor, A., \& Birjandi, P. (1994). Language skills testing: From theory to practice. Tehran, Iran: SAMT Publications.

Hyland, K. (2009). Academic discourse. English in a 
global context. London, UK: Continuum.

Milrud, R.P.(2005). Metodika prepodavaniya angliyskogo yazyka [English teaching methodology]. Moscow, Russia: Drofa.

Sahanaya, W., Lindeck, J., \& Stewart, R. (2006). Preparation and practice. Reading and writing. Academic module. Oxford, UK: OUP.

Sommer, R. F. (1989). Teaching writing to adults: Strategies and concepts for improving learner performance. San Francisco, CA: Jossey-Bass.

Tatarinova, M. A. (2005). Teoreticheskiye osnovy sozdaniya $i$ ispolzovaniya distantsionnogo kursa obucheniya inoyazychnoy pis'mennoy rechi dlya studentov lingvisticheskogo vuza [The theoretical basis for the creation and use of distance training course of writing in foreign languages for students of linguistics university]. Moscow, Russia: RAO.

Velikaya, E. V. (2015). New approaches to teacher development in an EAP context. Journal of Language and Education, 1(2), 56-62.

Widdowson, H. G. (2003). Defining issues in English language teaching. Oxford, UK: OUP.

Wray, D., \& Lewis, M. (1997). Teaching factual writing. The Australian Journal of Language and Literacy, 20(2), 43-52.

Zhurbenko, N. L. (2008). Metodika obucheniya sozdaniyu pis'mennykh vtorichnykh inoyazychnykh tekstov na osnove resursov [Training in the creation of secondary texts in foreign languages]. Moscow, Russia: Moscow State University.

Zimnyaya, I. A. (2000). Pedagogicheskaya psikhologiya [Educational psychology]. Moscow, Russia: Logos. 